\title{
Prognostic value of Golgi P 73 and Beta 2-microglobulin in patients with Viral Hepatitis B
}

\author{
Ozcan Deveci'®, Ibrahim Kaplan³, Recep Tekin², Mustafa Kemal Celen², Fatma Bozkurt², \\ Emel Aslan², Serkan Cerrah ${ }^{5}$ and Saim Dayan ${ }^{2}$
}

1Department of Infectious Diseases and Clinical Microbiology, Medical Park Hospital, Batman, Turkey; ${ }^{2}$ Department of Infectious Diseases and Clinical Microbiology, Faculty of Medicine, University of Dicle, Diyarbakir, Turkey; ${ }^{3}$ Departmant of Medical Biochemistry and Clinical Biochemistry, Faculty of Medicine, University of Dicle, Diyarbakir, Turkey; ${ }^{4}$ Department of Medical Microbiology, University of SelahaddinEyyubi, Diyarbakir, Turkey; ${ }^{5}$ Department of Gastroenterology, Erzurum Training and Research Hospital, Erzurum, Turkey

Previous studies detected higher Golgi protein 73 levels in the serum of patients with chronic liver disease. The Beta-2 microglobulin levels were also observed to be higher in patients with chronic hepatitis B infection compared to the inactive carriers and the protein plays an important role in the response to viral infections. The aim of the present study was to assess the liver fibrosis through non-invasive methods in chronic hepatitis B patients. Three groups were included in the study. The first group comprised of the patients who were admitted to the Infectious Diseases and Clinical Microbiology clinic to undergo a liver biopsy, while the second group included the patients who were admitted inactive hepatitis B carriers. The third group comprised the healthy controls. The Golgi p-73 and Beta-2 microglobulin levels in the plasma were determined using the ELISA method. Beta-2 microglobulin level was highest in the patients group and the difference was statistically significant. No significant difference was observed between the carriers group and the group of healthy controls. The Golgi P-73 values were significantly higher in the patients group in comparison to both other groups. However, the mean Golgi p-73 value was also significantly higher in the carrier group compared to the control group. In patients who are followed up with the diagnosis of chronic hepatitis $B$ and who have undergone biopsies as candidates for treatment, the Beta-2 microglobulin and Golgi p-73 values may be important markers since they indicate the extent of the liver damage.

Key words: Golgi protein-73, Beta-2 microglobulin, prognosis, Hepatitis B

Received: 08 February, 2016; revised: 10 April, 2016; accepted: 07 November, 2016; available on-line: 19 March, 2020

$\square$ e-mail: ozcandeveci1@hotmail.com

Abbreviations: HBV, Hepatitis B virus, GP-73, Golgi protein 73 CHB, chronic hepatitis $B, \beta-2$ MG, Beta-2 microglobulin, ALT, alanine aminotransferase, AST, aspartate aminotransferase

\section{INTRODUCTION}

The hepatitis B virus (HBV) is a highly contagious virus affecting approximately two billion people worldwide (EASL, 2012). About 240 million people have chronic hepatitis B infections and 600 thousand deaths occur due to acute and chronic hepatitis B every year (WHO, 2013). HBV is also an important risk factor in acute and chronic liver disease (Zhou et al., 2009). Chronic HBV infection leads to progressive liver damage and liver fi- brosis. Therefore, the description of an accurate method to evaluate liver damage and liver fibrosis is vital for the patients with chronic HBV infection. Currently, the lack of an accurate, reproducible and practical method to show the degree of the liver damage and liver fibrosis in patients with $\mathrm{HBV}$ is a serious limitation in the clinical management of this disease. The existing clinical methods for this purpose are ultrasonography, liver function tests, coagulation tests, and the serum markers of liver fibrosis which may reflect the disease progression in patients with chronic HBV (Rotman et al., 2009). Liver biopsy indicates the progress of the liver disease in the patients with chronic hepatitis B (CHB) (EASL, 2012). However, liver biopsy is a method with limited application in the clinic due to its invasive nature.Therefore, simple and non-invasive serum markers should be determined in chronic hepatitis B patients in order to evaluate the disease progress. The Golgi protein 73(GP -73 ) is a newly-described transmembrane protein released from the human epithelial cells (Kladney et al., 2000). In normal liver tissue, GP-73 is primarily released from the biliary epithelial cells and rarely from the healthy hepatocytes (Riener et al., 2009; Kladney et al., 2002). Studies showed that the hepatocellular GP-73 mRNA levels and protein release increase independently from the etiology and the concurrent disease in patients with acute and chronic hepatitis (Kladney et al., 2002; Sun et al., 2011). Higher GP-73 protein concentrations were also demonstrated to be associated with chronic liver disease in various studies (Sun et al., 2011; Iftikhar et al., 2004). The Beta-2 microglobulin ( $\beta-2 \mathrm{MG})$, which is an integral part of the human leukocyte antigen class 1 (HLA-1), is a protein with low molecular weight present in every cell that contains a nucleus. HLA-1 is found on the surface of the T- and B-lymphocytes and in various organs(Elefsiniotis et al., 2004). Studies reported higher serum $\beta-2$ MG levels in patients with acute hepatitis $B$, chronic hepatitis B, hepatic cirrhosis, and in inactive hepatitis B carriers (Kieslichova et al., 2009; Kim et al., 2011). The aim of the present study was to assess the usefulness of the non-invasive GP-73 and $\beta-2$ MG tests as markers of liver damage in patients with hepatitis B.

\section{MATERIAL AND METHOD}

The study was conducted in aprospective manner on patients who had undergone biopsies due to chronic hepatitis B (Group 1), on inactive HBsAg carriers (Group 2), and healthy controls (Group 3) at the Dicle University Medical Faculty, Infectious Diseases and Mi- 
crobiology Department between January 2012 and January 2014.

Inclusion criteria (13 Anna et al., 2011).

Group 1: Patients who had undergone biopsies due to chronic Hep $B$

(1) HBsAg-positive for more than 6 months,

(2) ALT value greater than 1.5 times the upper normal value limit (normally, the ALT value is below 40 $\mathrm{IU} / \mathrm{mL}$ ),

(3) HBV DNA $\geq 100000$ copies $/ \mathrm{mL}$ (20000 IU/ $\mathrm{mL}$ ) in those positive for the hepatitis $\mathrm{Be}$ antigen (HBeAg-positive),

(4) $\mathrm{HBV} \mathrm{DNA} \geq 10000$ copies $/ \mathrm{mL}(2000 \mathrm{IU} / \mathrm{mL})$ in those $\mathrm{HBeAg}$-negative, and

(5) Fibrosis $\geq 2$ in the histopathological evaluation of the liver

\section{Group 2: Inactive carriers}

(1) HBsAg-positive,

(2) Normal ALT values,

(3) HBeAg-negative, and

(4) HBV DNA $\leq 10000$ copies/mL (2000 IU/mL)

Group 3: Control group comprising $\mathrm{HBsAg-negative}$ and antiHBc-total negative patients.

Exclusion criteria. Diabetes mellitus, liver cirrhosis, hypertension, coronary artery disease, chronic obstructive pulmonary disease, corticosteroid treatment, malignancies, morbid obesity, pregnancy, liver and kidney failure, and smoking were the criteria for the exclusion from the study.

All the patients with chronic hepatitis B had undergone biopsies before the treatment. The patients' age, gender, and $\mathrm{HBsAg}, \mathrm{HBeAg}$, antiHBe, ALT, AST and HBV DNA values were recorded. In addition, the fibrosis scores of the chronic hepatitis B patients based on the biopsy results were also recorded.The ALT and AST tests were conducted at the central laboratory of the Dicle University Medical Faculty through the spectrophotometric method (Architect CT16000 Abbott, USA).The DNA levels were tested using the COBAS ${ }^{\circledR}$ AmpliPrep Total Nucleic Acid Isolation Kit (Roche Molecular Systems Inc., Branchburg, NJ, USA). After the DNA was isolated, the HBV DNA levels were evaluated with the COBAS ${ }^{\circledR}$ AmpliPrep/COBAS ${ }^{\circledR}$ Taqman $^{\circledR}$ HBV Test v2.0 (Roche Molecular Systems Inc., Branchburg, NJ, USA). The HBV DNA levels of the patients were expressed in $\mathrm{IU} / \mathrm{ml}$. The sera collected during the study were stored at $-70^{\circ} \mathrm{C}$. Subsequently, the GP-73 in the serum was studied with the Human Golgi Protein 73 (GP-73) ELISA (enzyme-linked immunosorbent assay) kit (Hangzhou Eastbiopharm Co., LTD, Hangzhou, China). The $\beta-2$ MG test was carried out using Human $\beta 2$ microglobulin ( $\beta$-2 MG) ELISA (enzyme-linked immunosorbent assay) kit (Hangzhou Eastbiopharm Co., LTD, Hangzhou, China).

The approval of the Dicle University Medical Faculty, Non-Invasive Clinical Studies Ethics Committee was obtained for the study. The GP-73 and $\beta-2$ MG ELISA kits required for the study were financed with the grant of the Dicle University Medical Faculty Scientific Research Project Coordinatorship.

Statistical Analyses. The obtained data were entered into the SPSS 15.0 statistical software. Categorical data were analysed using the Chi-square test. The normality of the distribution of the numeric data was tested with the Kolmogorov-Smirnov test. The normal data were analysed with Student's $t$-test, while those not displaying normal distribution were analysed using the Mann-Whitney $\mathrm{U}$ test. Statistical significance was based on a value of $p<0.05$.

\section{RESULTS}

For the purpose of the study, a total of 165 patients were enrolled, of which 60 were in Group 1, 55 were in Group 2, and 50 were in Group 3. There was no statistically significant difference between the groups in terms of the mean age and gender $(p=0.318$ and $p=0.133$, respectively) (Table 1$)$. The mean GP-73 value was highest in Group 1, while the lowest value was observed in Group 3. A statistically significant difference was observed between the three groups in terms of the mean GP-73 values $(p<00.1)$ (Table 1). There was no relationship between the GP-73 value and the fibrosis score, and the GP-73 value increase was not correlated with the fibrosis score increase. On the other hand, there was a statistically significant correlation of the HBV DNA level and the fibrosis score ( $\mathrm{r}=0295, p=0.022)$, and the fibrosis score was observed to increase together with the HBV DNA level. The $\beta-2$ MG values were statistically significantly different in the three groups. The highest mean value was found in Group 1, while the lowest mean value was observed in Group 3 (Table 1). There was no significant correlation between the fibrosis scores and the $\beta-2$ MG levels (Table 2). In terms of the association of the HBV DNA levels with the $\beta-2$ MG levels, the $\beta-2$ MG values were not observed to be positively correlated with the HBV DNA levels. This result was also statistically significant (Table 2).

\section{DISCUSSION}

GP-73 is primarily released from the biliary epithelial cells and rarely from the healthy hepatocytes (Riener et al., 2009; Kladney et al., 2002). Various studies demonstrated that higher GP-73 protein levels are correlated with chronic hepatic disease (Sun et al., 2011; Iftikhar et al., 2004). In patients with chronic hepatitis, the correlation between the serum GP-73 protein levels and the pathological grading of the liver or the fibrosis staging is yet to be cleared.The controversy on the relationship between the serum GP-73 protein levels and HBV replication still continues (Sterling et al., 2007; Chen et al., 2010). In the study by Zhengju et al. (Zhengiu et al., 2015), the serum GP-73 levels and the pathological grading of the liver were compared in patients with chronic hepatitis B.

Table 1. The clinical and demographic data of the study groups

\begin{tabular}{|c|c|c|c|c|}
\hline & $\begin{array}{c}\text { Group } 1 \\
n=33(\%)\end{array}$ & $\begin{array}{c}\text { Group } 2 \\
n=33(\%)\end{array}$ & $\begin{array}{l}\text { Group } 3 \\
n=33(\%)\end{array}$ & $p$ \\
\hline Mean age & $33.21 \pm 10.20$ & $36.73 \pm 11.54$ & $33.00 \pm 11.71$ & 0.318 \\
\hline Gender (M/F) & $21 / 12$ & $21 / 12$ & $14 / 19$ & 0.133 \\
\hline GP-73 & $31.38 \pm 3.01$ & $8.30 \pm 1.09$ & $6.66 \pm 7.62$ & $<0.001$ \\
\hline$\beta-2 M G$ & $22165.20 \pm 22764.4$ & $5715.78 \pm 10169.09$ & $4056.80 \pm 5620.63$ & $<0.001$ \\
\hline
\end{tabular}

$\beta$-2 MG, Beta-2 microglobulin; GP-73, Golgi protein 73. Statistical significance was based on a value of $p<0.05$ 
Table 2. Relationship of the HBV DNA and fibrosis scores with the GP-73 and $\beta-2$ MG levels

\begin{tabular}{|c|c|c|c|c|}
\hline & $r$ (HBVDNA) & $\mathrm{p}$ (HBVDNA) & $r$ (fibrosis score) & $p$ (fibrosis score) \\
\hline GP-73 & 0.040 & 0.762 & -0.160 & 0.223 \\
\hline$\beta-2 M G$ & 0.061 & 0.642 & -0.134 & 0.307 \\
\hline Fibrosis score & 0.295 & 0.022 & None & None \\
\hline
\end{tabular}

$\beta$-2 MG, Beta-2 microglobulin; GP-73, Golgi protein 73; r: correlation coefficient. Statistical significance was based on a value of $p<0.05$

According to the results of this study, the serum GP73 levels were correlated with the pathological grading of the liver and the GP-73 levels increased together with the pathological grade (Zhengiu et al., 2015). In a study conducted on the diagnostic and prognostic efficiency of the GP-73 protein in chronic liver disease due to chronic hepatitis B, GP-73 was demonstrated to be a beneficial marker both in the serum and histopathologically in the liver (Zhengiu et al., 2015). In our study, no correlation was observed between the serum GP-73 levels and the fibrosis score. This result was attributed to the limited number of patients in our study. We did not studied the GP-73 levels histopathologically in our patients. In a study by Liu and coworkers (2011) where they studied the serum GP-73 levels as a progression marker in patients with $\mathrm{CHB}$, no relationship was observed between the HBV DNA and the serum GP-73 levels. However, a correlation was found between the fibrosis score and the serum GP-73 levels (Liu et al., 2011). In our study, we observed a correlation between the HBV DNA levels and the fibrosis score and the fibrosis score increased together with the HBV DNA level. As part of the HLA complex, $\beta-2 \mathrm{MG}$ is responsible for the transmissionof the viral antigens of HBV onto the surface of the liver cells. Also, $\beta-2 \mathrm{MG}$ may be an indicator of HBV virus prevalence. (Abdolsamadi et al., 2013). In previous studies, significant increase was observed in the $\beta-2 \mathrm{MG}$ levels both in acute viral hepatitis and in patients with chronic hepatitis (Man et al., 1989; Yegane et al., 2004; Westral et al., 1984; Malaguarnera et al., 2000). In the study by Gunbay and coworkers (2014) where they evaluated $\beta-2 M G$ as a prognostic factor in the management of chronic hepatitis B, patients were divided into two groups with Group 1 comprising those who had biopsies due to the diagnosis of $\mathrm{CHB}$ and Group 2 including inactive $\mathrm{HBs} \mathrm{Ag}(+)$ carriers. When the $\beta-2 \mathrm{MG}$ levels in each group were compared, the $\beta-2$ MG levels in Group 1 were found to be higher. Among the patients in Group 1 who received pegylated interferon therapy, the $\beta-2$ MG levels were observed to diminish significantly in the second month of the therapy in comparison to pre-treatment values (Günbay et al., 2014). Also in our study, the highest $\beta-2$ MG levels were found in the patients who had undergone biopsies with the diagnosis of $\mathrm{CHB}$, which was in line with the previous studies. In a study conducted on patients with chronic hepatitis C, a significant correlation was observed between the histology activity index and the $\beta-2$ MG levels (Malaguarnera et al., 1994). No relationship was observed between the $\beta-2$ MG levels and the fibrosis score in our study. In a study investigating the relationship between HBV proliferation and $\beta-2 \mathrm{MG}$ from the saliva of the patients with $\mathrm{CHB}$, the $\beta-2$ MG levels were higher in the patients who were classified as HBV DNA positive with PCR test (Abdolsamadi et al., 2013). However, no relationship was observed between the HBV DNA level and the $\beta-2$ MG values in our study.

The greatest limitation of our study is the omission of a histopathological method to test the above-mentioned markers in the hepatic cells. However, we believe that our study may lead the way for further research in the future.

In conclusion, the $\beta-2 \mathrm{MG}$ and GP-73 levels may be the most important non-invasive diagnostic markers used to monitor the disease progression in patients to undergo a biopsy based on the diagnosis of CHB. Still, we are of the opinion that they cannot replace the biopsy, which is the gold standard of the diagnosis.

\section{REFERENCES}

Abdolsamadi H, Eini P, Ronasi N, Kaboli SA, Hajilooei M, MoghimBeigi A, Davoudi P, Motemayel FA, Shalmani HA (2013) Evalu-

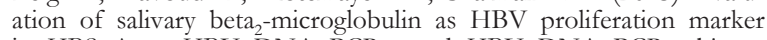
in HBS Ag+, HBV DNA PCR+ and HBV DNA PCR-subjects. Gastroenterol Hepatol Bed Bench 6 (Suppl 1): S105-S111. PMCID: PMC4017546

Chen WL, Peng T, Chen XP, et al (2010) GP73 test in diagnosis of liver diseases. Chin J Lab Med 33: 333-336 (In Chinese)

Elefsiniotis IS, Scarmeas N, Glynou I, Pantazis KD, Kada H, Mavrogiannis C (2004) Serum beta - $_{\text {microglobulin levels in }}$ hepatitis B e antigen-negative chronic hepatitis B patients under long term lamivudine monotherapy: relationship with virological breakthrough. Can J Gastroenterol 18: 307-313. https://doi. org/10.1155/2004/864292

Günbay SS, Deveci O, Agalar C, Demirdal T, Demirtürk N, Kaygusuz S, Kilıç D (2014) Beta $_{2}-$ Microglobulin as a prognostic factor in chronic hepatitis B treatment. Bosphorus Med J 1: 90-94

Iftikhar R, Kladney RD, Havlioglu N, Schmitt-Graff A, Gusmirovic I, Solomon S, Luxon BA, Bacon BR, Fimmel CJ (2004) Diseaseand cell-specific expression of GP73 in human liver disease. Am J Gastroenterol 99: 1087-1095. https://doi.org/10.1111/j.15720241.2004.30572.x

Kieslichová E, Schück O, Smrcková I, Granátová J, Skibová J, Merta D, Trunecka P (2009) Liver transplantation and peri-operative changes to renal function. Vnitr Lek 55: 1126 (In Czech). PMID: 20070028

Kim BK, Han KH, Ahn SH (2011) Hepatitis B virus serology to predict antiviral response in chronic hepatitis B. Digestion 84: 29-34. https://doi.org/10.1159/000334076

Kladney RD, Bulla GA, Guo L, Mason AL, Tollefson AE, Simon DJ, Koutoubi Z, Fimmel CJ (2000) GP73, a novel Golgi-localized protein upregulated by viral infection. Gene 249: 53-65. https://doi. org/10.1016/s0378-1119(00)00136-0

Kladney RD, Cui X, Bulla GA, Brunt EM, Fimmel CJ (2002) Expression of GP73, a resident Golgi membrane protein, in viral and nonviral liver disease. Hepatology 35: 1431-1440. https://doi. org/10.1053/jhep.2002.32525

Liu X, Wan X, Li Z, Lin C, Zhan Y, Lu X (2011) Golgi protein 73 (GP73), a useful serum marker in liver diseases. Clin Chem Lab Med 49: 1311-1316. https://doi.org/10.1515/CCLM.2011.640

Lok A.S.F, McMahon BJ (2009) AASLD Practice Guidelines Chronic Hepatitis B: Update

Malaguarnera M, Di Fazio I, Ferlito L, Pistone G, Laurino A, Vinci

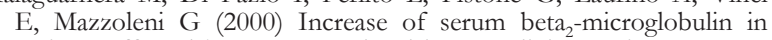
patients affected by HCV correlated hepatocellular carcinoma. Eur J Gastroenterol Hepatol 12: 937-939. https://doi.org/10.1097/00042737200012080-00014

Malaguernera M, Restuccia S, Di Fazio I, Zoccolo AM, Trovato BA, Pistone G (1994) Serum beta2-microglobulin in chronic hepatitis C. Dig Dis Sci 42: 762-766. https://doi.org/10.1023/a:1018855928753

Man R-A, Lindermans J, Schalm SW, Kate FJW (1989) $\beta_{2}-$ Microglobulin and antiviral therapy for chronic hepatitis type $B$. Antivir Res 11: 181-190

Papatheodoridis G, Buti M, Cornberg M, Janssen HLA, Mutimer D, Pol S, Raimondo G, Dusheiko G, Lok A, Marcellin P., European Association for the Study of the Liver: EASL clinical practice guidelines (2012) Management of chronic hepatitis B virus infection. J Hepatol 57: 167-185. https://doi.org/10.1016/j.jhep.2012.02.010 
Riener MO, Stenner F, Liewen H, Soll C, Breitenstein S, Pestalozzi BC, Samaras P, Probst-Hensch N, Hellerbrand C, Müllhaupt B, Clavien PA, Bahra M, Neuhaus P, Wild P, Fritzsche F, Moch H, Jochum W, Kristiansen G (2009) Golgi phosphoprotein 2 (GOLPH2) expression in liver tumors and its value as a serum marker in hepatocellular carcinomas. Hepatology 49: 1602-1609. https://doi. org/10.1002/hep.22843

Rotman Y, Brown TA, Hoofnagle JH (2009) Evaluation of the patient with hepatitis B. Hepatology 49 (Suppl 5): S22-S27. https://doi. org/10.1002/hep. 22976

Sterling RK, Jeffers L, Gordon F, Sherman M, Venook AP, Reddy KR, Satomura S, Schwartz ME (2007) Clinical utility of AFP-L3\% measurement in North American patients with HCV-related cirrhosis. Am J Gastroenterol 102: 2196-2205. https://doi. org/10.1111/j.1572-0241.2007.01405.x

Sun Y, Yang H, Mao Y, Xu H, Zhang J, Li G, Lu X, Sang X, Zhao H, Zhong S, Huang J, Zhang H (2011) Increased Golgi protein 73 expression in hepatocellular carcinoma tissue correlates with tumor aggression but not survival. J Gastroenterol Hepatol 26: 1207-1212. https://doi.org/10.1111/j.1440-1746.2011.06733.x
Westral R, Norkrans G, Weiland O, Schvarcz R, Fuchs D (1984) Lymphocyte subsets and $\beta_{2}$-microglobulin expression in chronic hapatitis $\mathrm{C} /$ non $\mathrm{A}$, non $\mathrm{B}$ : effects of interferon-alpha treatment. Clin Exp Immunol 87: 340-345

World Health Organization (2013) Hepatitis B Factsheet 204. http:// www.who.int/mediacentre/factsheets/fs204/en/index.html

Xu Z, Liu L, MS, Pan X, Wei K, Wei M, Liu L, Yang H, Liu Q (2015) Serum Golgi Protein 73 (GP73) is a diagnostic and prognostic marker of chronic HBV liver disease. Medicine 94: https://doi. org/10.1097/MD.0000000000000659

Xu Z, Pan X, We1 K, Ding H, We1 M, Yang H, Liu Q (2015) Serum Golgi protein 73 levels and liver pathological grading in cases of chronic hepatitis B. Mol Med Reports 11: 2644-2652. https://doi. org/10.3892/mmr.2014.3114

Yegane S, Revanli M, Taneli F (2004) The role of $\beta_{2}$-microglobulin levels in monitoring chronic Hepatitis B. Tohoko J Exp Med 203: 53-57. https://doi.org/10.1620/tjem.203.53

Zhou YH, Wu C, Zhuang H (2009) Vaccination against hepatitis B: the Chinese experience. Chin Med J (Engl) 122: 98-102. PMID: 19187625 